\title{
Chapter 4 Flipped classroom a model for autonomous learning
}

\section{Capítulo 4 Flipped classroom un modelo para el aprendizaje autónomo}

RAMÍREZ-HERNÁNDEZ, Moramay*, DÍAZ-ALVA, Angelina and FIGUEROA-MORENO, Gabriela Universidad Tecnológica de Tecámac, Information and Communication Technologies Division, Mexico.

ID $1^{\text {st }}$ Author: Moramay, Ramírez-Hernández, / ORC ID: 0000-0003-3813-5149, CVU CONACYT ID: 44090

ID $1^{\text {st }}$ Co-author: Angelina, Díaz-Alva / ORC ID: 0000-0002-2514-4989, CVU CONACYT ID: 509840

ID $2^{\text {nd }}$ Co-author: Gabriela, Figueroa-Moreno / ORC ID: 0000-0002-8509-1305, CVU CONACYT ID: 1023978

DOI: $10.35429 / \mathrm{H} .2021 .10 .53 .65$ 


\begin{abstract}
At the higher education level, autonomous learning is one of the most important challenges facing education today, especially with the current situation caused by the pandemic, where students must acquire good academic habits, work in a self-regulated manner and with their own criteria to support decision making. This paper describes the research conducted in a Technological University where the inverted classroom model was implemented in a subject to analyze the impact of the implementation of this model in the autonomous learning of students. The methodology used was based on a mixed type study, initially with an exploratory scope for the qualitative part and an experimental design for the quantitative part. The main contribution of this research is the Flipped Classroom Framework for its implementation for both teachers and students.
\end{abstract}

As far as the specific objectives are concerned, the first is to define the framework to facilitate the teaching-learning process using the flipped classroom model in the context of the Technological Universities model, the second is to know the advantages and disadvantages that the flipped classroom offers to the students and the third to propitiate the autonomous learning of the students of the subject of Multiplatform Mobile Development.

\title{
Flipped classroom, Autonomous learning, Educational technology, ICT
}

\section{Resumen}

A nivel superior, el aprendizaje autónomo es uno de los desafíos más importantes que se tiene la educación hoy en día, especialmente con la situación actual que se vive a raíz de la pandemia, donde los estudiantes deben adquirir buenos hábitos académicos, trabajar de manera autorregulada y con criterios propios para apoyar la toma de decisiones. El presente trabajo describe la investigación realizada en una Universidad Tecnológica donde se implementó el modelo de aula invertida en una asignatura para analizar el impacto de la implementación de dicho modelo en el aprendizaje autónomo de los estudiantes. La metodología utilizada se basó en un estudio de tipo mixto, inicialmente con un alcance exploratorio para la parte cualitativa y un diseño experimental para la parte cuantitativa. La principal contribución de esta investigación es el Flipped Classroom Framework para su implementación tanto para profesores como para estudiantes.

En cuanto a los objetivos específicos se refiere, el primero consiste en definir el marco de trabajo para facilitar el proceso de enseñanza-aprendizaje utilizando el modelo de flipped classroom en el contexto del modelo de las Universidades Tecnológicas, el segundo es conocer las ventajas y desventajas que el flipped classroom ofrece a los estudiantes y el tercero propiciar el aprendizaje autónomo de los estudiantes de la asignatura de Desarrollo Móvil Multiplataforma.

\section{Aula invertida, Aprendizaje autónomo, Tecnología educativa, TIC}

\subsection{Introduction}

Currently, as a result of the sudden changes that the pandemic has brought, particularly in the educational field, it is essential to update learning models and focus them on processes that allow students to better acquire knowledge.

It is for the above that Information and Communication Technologies (ICT) are very useful tools that are being used in conjunction with educational technology to enhance the autonomous work of students who today carry their teaching-learning process mainly in home.

For Del Arco, Flores and Silva 2019, "learning has ceased to be an internal and individual activity to become a collective and network activity", given the circumstances the role of the teacher has changed to be a mediator of learning that facilitates and enhances the process of acquiring knowledge to students. 
Virtual education has been a tool that has undoubtedly been used under the circumstances to have a closer relationship with students and face-to-face classes have been migrated to this format practically overnight. However, the use of technological tools that are used in virtual education does not guarantee the achievement of the expected learning, it is important that there is significant learning, centered on the student, which is individual and multidimensional.

As mentioned by Adriazola, Durán and Flores, 2020 "one of the potentialities that allows the implementation of ICT in education is that it favors the change of role between the teacher and the student", the teacher is now a facilitator that promotes autonomous work.

It should be noted that, although the flipped classroom has been used mainly in school-based courses, it can also be adapted to the virtual modality, mainly in b-learning with synchronous classes instead of face-to-face ones, since it is a flexible learning model with the support of ICT (Kardas \& Yesilyaprak, 2015).

In the flipped classroom model according to Erol 2020, the student plays an active role, knows the topic before starting the class, the teacher during class solves doubts and carries out activities focused on achieving the expected learning and focuses on the practice, after class learning activities and collaborative works are assigned mainly, all this with the support of ICT. Therefore, the flipped classroom is a more effective type of b-learning with greater advantages for students (Sanchéz-Cruzado and Sánchez-Compaña, 2020).

An important aspect that should be mentioned about this model is that it is closely related to the educational objectives of Bloom's taxonomy, where the first categories of lower order would be worked out of the classroom and the last categories of higher order in the synchronous class (Zainuddin and Halili, 2016).

On the other hand, autonomous learning is important at all educational levels, however, within the Technological Universities model it is considered one of the main objectives to be achieved by students. The educational model seeks the development of capacities and the achievement of meaningful learning, where the student controls their own learning, achieving self-directed learning.

Considering that the evaluation by competencies in Technological Universities is qualitative, students in the subjects are assigned an evaluation considering the criteria of: Not Accredited, Satisfactory, Outstanding and Autonomous, where the latter is only given to students who have demonstrated their competencies through independence or autonomy.

However, taking students to the autonomous level is not an easy task, it is a collective process that requires a lot of effort and time on the part of teachers, but above all a lot of commitment on the part of the students.

One of the causes that hinder autonomous learning in institutions is that students are little involved in their teaching-learning process, so with the flipped classroom model it is intended that they play a more active role with the realization of activities that promote that autonomy (Balçikanli, 2010).

Derived from the above, the proposal for the implementation of the flipped classroom is made as a strategy to strengthen the autonomous learning of students of Technological Universities. This model was chosen because it is flexible, it can be adapted to various learning models, it promotes collaborative work and uses ICT as support tools for interactive experiences, something very favorable in these times of the pandemic.

The hypothesis proposed for this work is that: With the implementation of the flipped classroom, the autonomous learning of the students at the Technological Universities can be improved. 
This chapter consists of 8 sections such as; introduction, where a general explanation of the subject is given, state of the art in which a compilation of the most representative and current information regarding the topics of flipped classroom, autonomous learning, and evaluation of learning in Technological Universities is presented, then in The methodology section to be developed describes the process based on the scientific method of how the work was carried out, then there is the section of the framework of the flipped classroom for the implementation in which it is described for both teachers and students, also The results section is included from both the qualitative and quantitative point of view, additionally the conclusions section where the most outstanding contributions of the work are highlighted, and finally the references section where the consulted sources that support the research are included.

\subsection{State of the art}

\subsubsection{Flipped classroom}

The flipped classroom model is an innovative methodology, it was proposed by (Bergmann and Sams, 2012), this model applies constructivism and considers the student as the center of the teaching-learning process, in addition to which it can be applied in flexible and open environments (Artero and Domeque, 2018).

The flipped classroom is considered a blended learning modality that includes a comprehensive approach, which places special emphasis on the individual needs of students, with learning that takes place outside the classroom, in addition to promoting interest and motivation, giving it a twist to traditional education with the active participation of the student (Aguilera-Ruiz et al 2017). There are several definitions around this concept, the most representative ones are shown below:

The inverted classroom or flipped classroom is a teaching method whose main objective is that the student to assume a much more active role in their learning process than the one they have traditionally been occupying" (Berenguer, 2016).

According to García-Gil and Cremades-Andreu 2019, the flipped classroom model is "in which the usual practice of reserving class time for instruction or the narrative implementation of theoretical knowledge is altered, while these are complemented with practical activities carried out outside of school hours (the usual tasks, exercises or work)".

For Sánchez, Ruiz and Sánchez 2017, "it is a pedagogical approach that consists of using the time outside the classroom to carry out certain learning processes that are traditionally done within the classroom and, for its part, within the classroom, with the presence, teacher's guide and experience, time is used to enhance and facilitate other processes of knowledge acquisition and practice, in applying concepts and participating creatively in the contents."

As Artero and Domeque 2018 mention, the flipped classroom has changed the way of teaching in a traditional way to a disruptive way, where the student has a more active role prior to the face-to-face or synchronous class and the time in the classroom is optimized for the core part of the class, doing practices, solving doubts, discussing or reflecting, in addition to making a more personalized teachinglearning process for students who require it.

Additionally, according to Flores, Del Arco and Silva 2016, evaluation is an important part of the flipped classroom model, and it should be:

- Integral.

- $\quad$ Reflective.

- Responsible.

- $\quad$ Shared.

- Competent. 
However, as mentioned by Díaz, Carraga and Serra, 2020, it is important to consider that each student has their own rhythm for assimilating content and building knowledge.

\subsubsection{Autonomous learning}

According to Sarramona 2011, the term "autonomy means to govern oneself", this term has become very common in the educational field.

As mentioned by Paladines-Ugalde 2016, educational autonomy is not an individual process but rather a generic competence that must be given collectively to achieve true learning in the classroom. At the higher level, students are expected to achieve this competence upon graduation since it is one of the best tools for permanent and continuous learning for life.

Autonomous learning is defined as "the student's orientation to take responsibility for their own learning, which leads them to use cognitive and metacognitive processes to learn strategically and flexibly according to the learning objective" (Reyes, 2017). But it also implies increased motivation, creativity, maturity and construction of one's own knowledge.

Autonomous learning is also known as self-regulated learning, self-learning or self-managed learning, where the student must learn by himself in a critical way and the main objective is to learn to learn.

In addition to the above, autonomous learning has many benefits for students, among which are; it encourages human development, encourages metacognitive development, organization of the learning process itself, increases self-esteem, improves confidence, as well as strengthening integral development.

However, there is a very close relationship between ICT and autonomous learning, for Espinoza and Velázquez 2017, ICT is only a mean for students to achieve autonomous learning, since it is necessary that they develop true learning in the classroom by means of practice and responsibility. It is worth mentioning that ICTs are tools that support constructivist learning, autonomous learning and contribute to the teaching-learning process to achieve the objectives of the educational programs of Technological Universities.

\subsubsection{Assessment of learning in Technological Universities}

Since they were created, the Technological Universities have had six attributes which are: quality, relevance, intensity, continuity, versatility and flexibility. It should be noted that the quality attribute refers to the culture of both internal and external evaluation (CGUT, 2008).

Technological Universities are currently working under a model based on competencies, which are made up of various components such as; knowledge (knowing), abilities and skills (knowing how to do) as well as attitudes and values (knowing how to be and live together).

With reference to the evaluation of the subjects that are not integrative, the learning result of each competence unit is expressed in an alphabetical and qualitative scale, where the levels are: Satisfactory (SA), Outstanding (DE), Autonomous (AU), Not accredited (NA) or Without evaluation (SE). A student obtains SA as long as he achieves the learning results, obtains DE when the learning results have been achieved and exceeds the established requirements, obtains AU when he exceeds the learning result in different contexts, obtains NA if he has not met the results of learning and SE in case of not complying with the learning result or with the minimum attendance established in the regulation.

In particular, the student who obtains an Autonomous assessment is expected to be a student with high responsibility and initiative, demonstrating both in knowledge and in cognitive, metacognitive and learning skills, as well as in their attitudes and values. 


\subsection{Methodology to be developed}

For the development of this project a mixed type study was carried out, initially with an exploratory scope using a mainly qualitative approach where a documentary research was carried out, later to measure the results the quantitative approach was used. Regarding the design of the research for the quantitative part, it was experimental with two groups, one experimental and the other control.

\subsubsection{Participants}

This work was developed in the semester September-December 2020 at a Technological University in Mexico, in the Information and Communication Technologies division. Regarding the population, a selection was made of the 28 students of the 5th semester of the Higher University Technician in Information and Communication Technologies career: Multiplatform Software Development Area, the experiment was applied in the Development Multiplatform Mobile subject.

As recommended by Hernández-Sampieri et al. (2003), the students were divided into 2 groups of the same size to guarantee internal validity and completely at random, G1 was considered as the experimental group and G2 as the control group, both with 14 students each.

For the present work, the following variables were defined:

- Dependent variable: autonomous learning.

- Independent variable: flipped classroom.

\subsection{Flipped classroom framework for implementation}

Once the documentary research was carried out, the framework was generated to implement it in the course, taking into account the model of Technological Universities and that classes are currently being given remotely and synchronously through videoconferencing platforms. It is important to mention that the work of the flipped classroom as described by Santiago 2016, not only occurs during class but also before and after it, on the other hand, it is an activity in which the role of the teacher and the student are vital importance, for this reason the activities to be carried out by each are described below.

\subsubsection{Teacher activities}

First, the activities that the teacher must carry out were defined considering the three important moments for this model, Table 4.1 shows the identified activities.

Table 4.1 Teacher activities within the framework of the flipped classroom

\begin{tabular}{|c|c|c|}
\hline Before the Class & During the Class & After the Class \\
\hline $\begin{array}{l}\text { Carry out the planning of } \\
\text { activities. } \\
\text { Create materials according to the } \\
\text { learning objectives that introduce } \\
\text { the student to the subject and } \\
\text { promote meaningful learning. } \\
\text { - Share attractive materials such as; } \\
\text { videos, learning objects, } \\
\text { interactive multimedia, etc. } \\
\text { - Promote educational autonomy } \\
\text { considering knowing, doing and } \\
\text { being. } \\
\text { Define work prior to class. } \\
\text { Generate the sequence and } \\
\text { structure of the synchronous } \\
\text { session. }\end{array}$ & $\begin{array}{l}\text { Act as a guide and motivate } \\
\text { students. } \\
\text { - Clarify and provide feedback on } \\
\text { group and personalized doubts. } \\
\text { Apply the constructivist method } \\
\text { and reinforce knowledge. } \\
\text { - Facilitate and enhance learning in } \\
\text { an environment of trust. } \\
\text { - } \quad \text { Encourage student participation. } \\
\text { - Generate learning activities, } \\
\text { mainly oriented to the practical } \\
\text { part. } \\
\text { Give feedback in an agile way. } \\
\text { Make formative evaluation } \\
\text { considering knowing, doing and } \\
\text { being. }\end{array}$ & 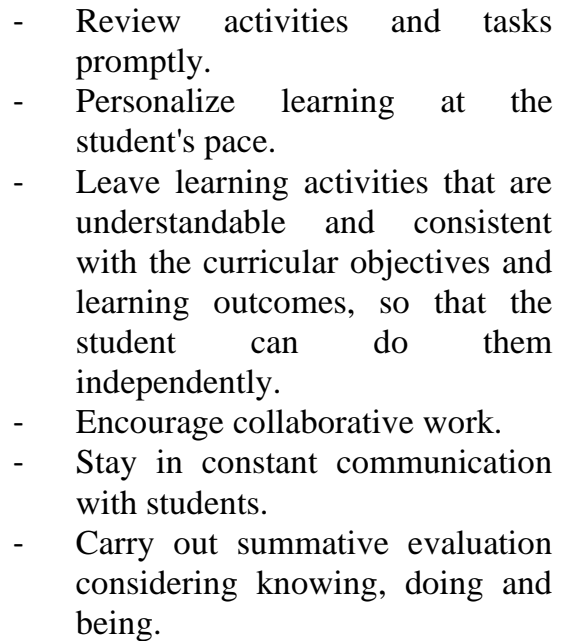 \\
\hline
\end{tabular}




\subsubsection{Student activities}

The activities to be carried out by the student were also defined. Table 4.2 shows the details.

Table 4.2 Student activities within the framework of the flipped classroom

\begin{tabular}{|c|c|c|}
\hline Before the Class & During the Class & After the Class \\
\hline $\begin{array}{l}\text { - Review previously assigned topics } \\
\text { and materials. } \\
\text { - Carry out the activities prior to the } \\
\text { synchronous session. } \\
\text { Investigate more about the topic } \\
\text { that will be covered in the } \\
\text { synchronous class. } \\
\text { - Prepare a guide with the list of } \\
\text { doubts or questions on the subject. } \\
\text { - Develop study habits. } \\
\text { - Have their own study criteria and } \\
\text { methods. }\end{array}$ & 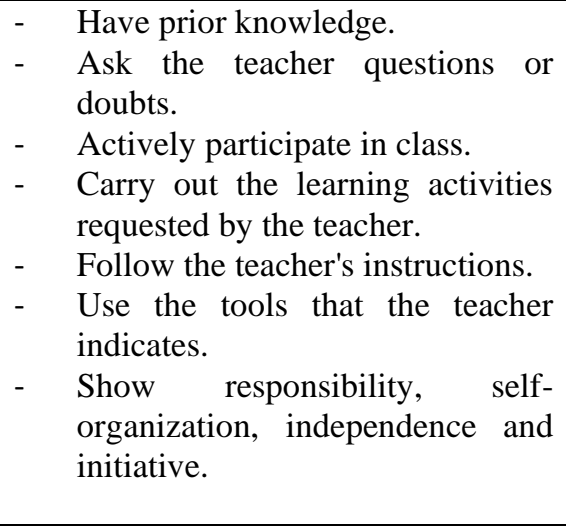 & 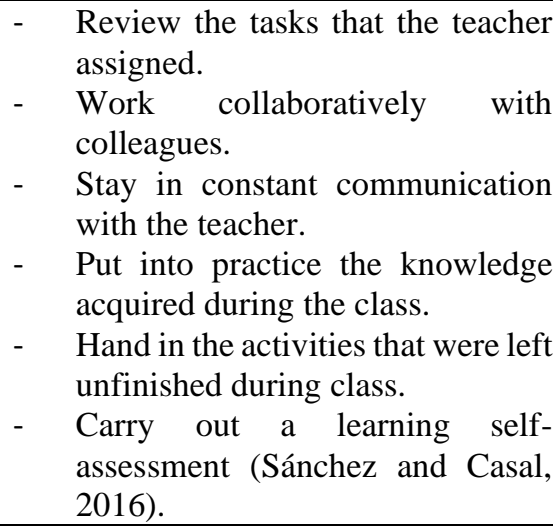 \\
\hline
\end{tabular}

\section{Source: Own elaboration}

It should be noted that this information from the framework was made known to both, the teacher and the students, belonging to G1 (experimental group) so that it was carried out during the 105 hours of the course, while G2 (group control) was working as normal, both with the same teacher.

\subsubsection{Evaluation of activities}

To evaluate the implementation of the activities, a teacher was appointed as a monitor of the experimental group sessions so that with the help of a checklist he was verifying compliance with them before, during and after classes. The monitor was constantly providing feedback, both to teachers and students, so that during the course they could carry out the activities defined within the framework of the flipped classroom.

\subsection{Results}

\subsubsection{Qualitative}

Undoubtedly, the implementation of the course through the flipped classroom model was a creative challenge for those involved, at the beginning mainly for the teacher who had to follow the proposed framework to promote the autonomous work of the students, it was continuously monitored the performance of the teacher before, during and after the sessions, as well as the students were monitored, taking in addition to the mentioned checklist, an observation log, and based on the annotations made and the experience obtained, it was possible to corroborate various advantages for students and teachers as mentioned (Gilboy, Heinerichs \& Pazzaglia, 2015; Pienta, 2016), which are shown in Table 4.3.

Table 4.3 Advantages of the flipped classroom

\begin{tabular}{|c|c|}
\hline Advantages for the student & Advantages for the teacher \\
\hline 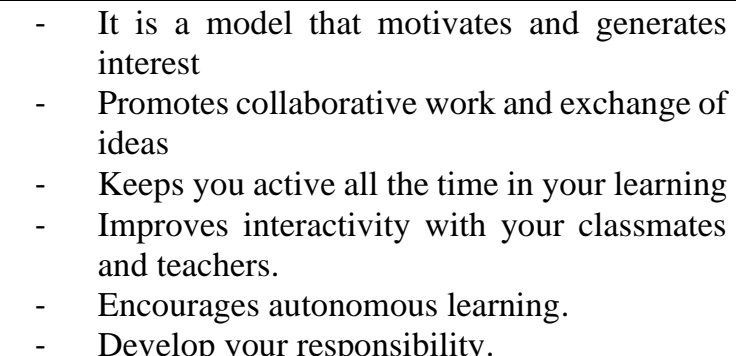 & $\begin{array}{l}\text { - There is better use of the time of the face-to-face or } \\
\text { synchronous session } \\
\text { - It is applicable for different learning styles and } \\
\text { modalities } \\
\text { - } \quad \text { It can be applied face-to-face, virtual or mixed } \\
\text { - } \quad \text { Feedback is more agile } \\
\text { - } \quad \text { Greater participation in class } \\
\text { - Its main role is as a mediator of learning }\end{array}$ \\
\hline
\end{tabular}


At the beginning, it was quite a challenge for the teacher to implement the flipped classroom model in the Multiplatform Mobile Design subject in such a way that it was meaningful and studentcentered. But the importance of the active role of the student should also be highlighted, since it was totally different from what he was used to. However, it was also detected that this model also has some disadvantages which are shown in Table 4.4.

Table 4.4 Disadvantages of the flipped classroom

\begin{tabular}{|l|l|}
\hline \multicolumn{2}{|c|}{ Disadvantages for the student } \\
- $\begin{array}{l}\text { At the beginning it is complicated and there is resistance } \\
\text { to the implementation of the model due to the role } \\
\text { change it implies. }\end{array}$ & $\begin{array}{l}\text { You have to make a great effort to drive the model } \\
\text { correctly by updating its programming. } \\
\text { It takes a long time to create the various educational } \\
\text { resources. }\end{array}$ \\
$\begin{array}{l}\text { It is high cost since it is necessary to use electronic } \\
\text { devices constantly. }\end{array}$ & $\begin{array}{l}\text { A constant guide is required for the development of } \\
\text { activities. }\end{array}$ \\
- $\begin{array}{l}\text { Internet access is required. } \\
\text { If the teacher does not lead the } 3 \text { moments correctly, it } \\
\text { is difficult to give continuity. }\end{array}$ & $\begin{array}{l}\text { It is necessary to have a greater reflection of the learning } \\
\text { models implemented in technological platforms. }\end{array}$ \\
- Usually outside of the synchronous class the student \\
$\begin{array}{l}\text { works individually. } \\
\text { It is difficult to change the role at the beginning and } \\
\text { leave aside the traditional model. }\end{array}$
\end{tabular}

\section{Source: Own elaboration}

At the beginning it was difficult to get used to the change of model, mainly for the students the change towards a disruptive model such as the flipped classroom was slow, but despite this, over time they adapted and their performance improved, something important that was detected is that precise instructions are very important to strengthen autonomous learning. As for the teachers, at the beginning it was also a bit difficult, especially because of the time they had to invest to prepare the resources prior to the synchronous sessions and that their function was mainly as a mediator or facilitator.

In this regard, despite the disadvantages detected in this implementation, the flipped classroom model is considered a positive perception for students, since the impact it produces on them is very pragmatic and adapts very well to different learning styles, generating good habits by giving them greater responsibility both in thinking and in action, allowing them to define their own criteria, learning methods, as well as promoting collaborative work.

\subsubsection{Quantitative}

As far as the quantitative part is concerned, to measure autonomous learning, the groups were evaluated under the same criteria of the competency model of the Technological University and the Multiplatform Mobile Development subject where the criteria to achieve the results of learning are clearly defined, with the only difference that in the experimental group during the quarter the flipped classroom model was applied and in the control group a traditional class was carried out.

Both groups were evaluated during the 3 partial periods established by the Technological Universities model and attached to the evaluation scheme of the subject, as far as time is concerned, the first partial is evaluated in week 5, the second partial is evaluated in the week 10, the third partial in week 14 and the final evaluation is carried out in week 15.

As mentioned above, the evaluation scale is qualitative and the levels are: Satisfactory (SA), Outstanding (DE), Autonomous (AU), Not accredited (NA) and Without evaluation (SE), Table 4.5 shows the results obtained during the quarter for the experimental group while Table 1.6 shows the results of the control group. 
Table 4.5 Results of G1 (experimental group)

\begin{tabular}{|c|c|c|c|c|c|c|}
\hline & \multicolumn{2}{|c|}{ Gender } & \multirow{2}{*}{$\begin{array}{c}1^{\text {st }} \text { Partial } \\
\text { Assessment }\end{array}$} & \multirow{2}{*}{$\begin{array}{l}2^{\text {nd }} \text { Partial } \\
\text { Assessment }\end{array}$} & \multirow{2}{*}{$\begin{array}{l}3^{\text {rd }} \text { Partial } \\
\text { Assessment }\end{array}$} & \multirow{2}{*}{$\begin{array}{c}\text { Final } \\
\text { Evaluation }\end{array}$} \\
\hline & $\mathbf{F}$ & $\mathbf{M}$ & & & & \\
\hline Student 1 & & $\mathrm{X}$ & $\mathrm{AU}$ & NA & $\mathrm{DE}$ & SA \\
\hline Student 2 & & $\mathrm{X}$ & $\overline{\mathrm{AU}}$ & NA & $\overline{\mathrm{AU}}$ & $\mathrm{DE}$ \\
\hline Student 3 & & $\mathrm{X}$ & $\mathrm{AU}$ & $\overline{A U}$ & $\mathrm{AU}$ & $\mathrm{AU}$ \\
\hline Student 4 & & $X$ & $\mathrm{DE}$ & NA & $\mathrm{AU}$ & $\mathrm{DE}$ \\
\hline Student 5 & $X$ & & $\mathrm{AU}$ & SA & $\mathrm{AU}$ & $\mathrm{AU}$ \\
\hline Student 6 & $X$ & & $\mathrm{AU}$ & $\mathrm{DE}$ & $\mathrm{AU}$ & $\mathrm{AU}$ \\
\hline Student 7 & & $\mathrm{X}$ & $\mathrm{AU}$ & SA & $\mathrm{AU}$ & $\mathrm{AU}$ \\
\hline Student 8 & & $X$ & SA & NA & SA & SA \\
\hline Student 9 & & $X$ & $\mathrm{AU}$ & $\mathrm{DE}$ & $\mathrm{AU}$ & $\mathrm{AU}$ \\
\hline Student 10 & & $\mathrm{X}$ & $\mathrm{AU}$ & SA & $\mathrm{DE}$ & $\mathrm{DE}$ \\
\hline Student 11 & & $\bar{X}$ & $\overline{\mathrm{DE}}$ & NA & $\mathrm{AU}$ & SA \\
\hline Student 12 & & $\mathrm{X}$ & $\mathrm{AU}$ & $\mathrm{AU}$ & $\mathrm{AU}$ & $\mathrm{AU}$ \\
\hline Student 13 & $\mathrm{X}$ & & SA & NA & SA & SA \\
\hline Student 14 & $\mathrm{X}$ & & $\mathrm{AU}$ & NA & $\mathrm{DE}$ & SA \\
\hline $\begin{array}{l}\text { Total } \\
\text { students }\end{array}$ & utor & nous & 10 & 2 & 9 & 6 \\
\hline$\%$ of autono & us s & dents & $71.4 \%$ & $14.2 \%$ & $64.2 \%$ & $42.8 \%$ \\
\hline
\end{tabular}

Source: Own elaboration

Table 4.6 Results of G2 (control group)

\begin{tabular}{|c|c|c|c|c|c|c|}
\hline & \multicolumn{2}{|c|}{ Gender } & $\begin{array}{l}1^{\text {st }} \text { Partial } \\
\text { Assessment }\end{array}$ & $\begin{array}{l}2^{\text {nd }} \text { Partial } \\
\text { Assessment }\end{array}$ & $\begin{array}{c}\mathbf{3}^{\text {rd }} \text { Partial } \\
\text { Assessment }\end{array}$ & $\begin{array}{c}\text { Final } \\
\text { Evaluation }\end{array}$ \\
\hline Student 1 & & $X$ & $\mathrm{DE}$ & $\mathrm{AU}$ & $\mathrm{AU}$ & AU \\
\hline Student 2 & & $\mathrm{X}$ & SA & NA & $\mathrm{DE}$ & SA \\
\hline Student 3 & $\mathrm{X}$ & & NA & NA & NA & NA \\
\hline Student 4 & & $X$ & DE & SA & $\mathrm{AU}$ & DE \\
\hline Student 5 & & $\mathrm{X}$ & NA & NA & $\mathrm{AU}$ & SA \\
\hline Student 6 & & $\mathrm{X}$ & SA & NA & $\mathrm{DE}$ & SA \\
\hline Student 7 & & $\mathrm{X}$ & $\mathrm{AU}$ & $\mathrm{AU}$ & $\mathrm{AU}$ & $\mathrm{AU}$ \\
\hline Student 8 & & $\mathrm{X}$ & $\mathrm{AU}$ & NA & NA & NA \\
\hline Student 9 & & $\mathrm{X}$ & $\mathrm{AU}$ & NA & $\mathrm{AU}$ & $\mathrm{DE}$ \\
\hline Student 10 & & $X$ & $\mathrm{DE}$ & NA & $\mathrm{AU}$ & $\mathrm{DE}$ \\
\hline Student 11 & $X$ & & $\mathrm{DE}$ & SA & $\mathrm{AU}$ & $\mathrm{DE}$ \\
\hline Student 12 & & $\mathrm{X}$ & NA & SA & $\overline{\mathrm{DE}}$ & SA \\
\hline Student 13 & & $\mathrm{X}$ & NA & NA & SA & SA \\
\hline Student 14 & & $\mathrm{X}$ & $\mathrm{DE}$ & NA & $\mathrm{AU}$ & $\mathrm{DE}$ \\
\hline $\begin{array}{l}\text { Total } \\
\text { students }\end{array}$ & \multicolumn{2}{|c|}{ autonomous } & 3 & 2 & 8 & 2 \\
\hline \multicolumn{3}{|c|}{$\%$ of autonomous students } & $21.4 \%$ & $14.2 \%$ & $57.1 \%$ & $14.2 \%$ \\
\hline
\end{tabular}

\section{Source: Own elaboration}

As can be seen by comparing the tables, in the $1^{\text {st }}$ partial the students of the experimental group obtained better results than the students of the control group, this is mainly due to the fact that the course was carried out centered on the student where it is reflected that the group experimental acquired better knowledge.

In the $2^{\text {nd }}$ partial assessment the results of both groups were practically the same, in the $3^{\text {rd }}$ partial the experimental group also obtained a greater number of autonomous students and in the final evaluation the experimental group obtained better results with which it can be seen that the application of flipped classroom promotes the autonomous work of students.

Graphic 4.1 shows the concentration of the evaluations of the experimental group, indicating the number and percentage of students who obtained each of the scale values. 
Graphic 4.1 G1 Scale Assessment Concentrate

G1 (Experimental group)

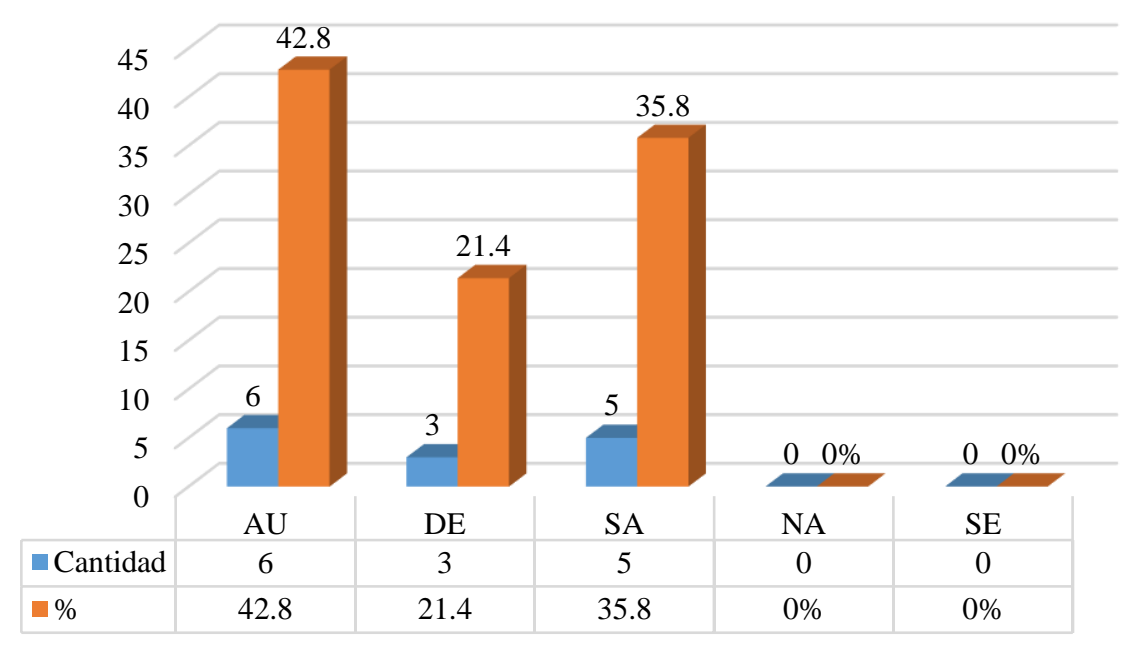

Source: Own elaboration

Graphic 4.2 shows the concentration of the evaluations of the control group, indicating the number and percentage of students who obtained each of the scale values.

Graphic 4.2 G2 Scale Assessment Concentrate

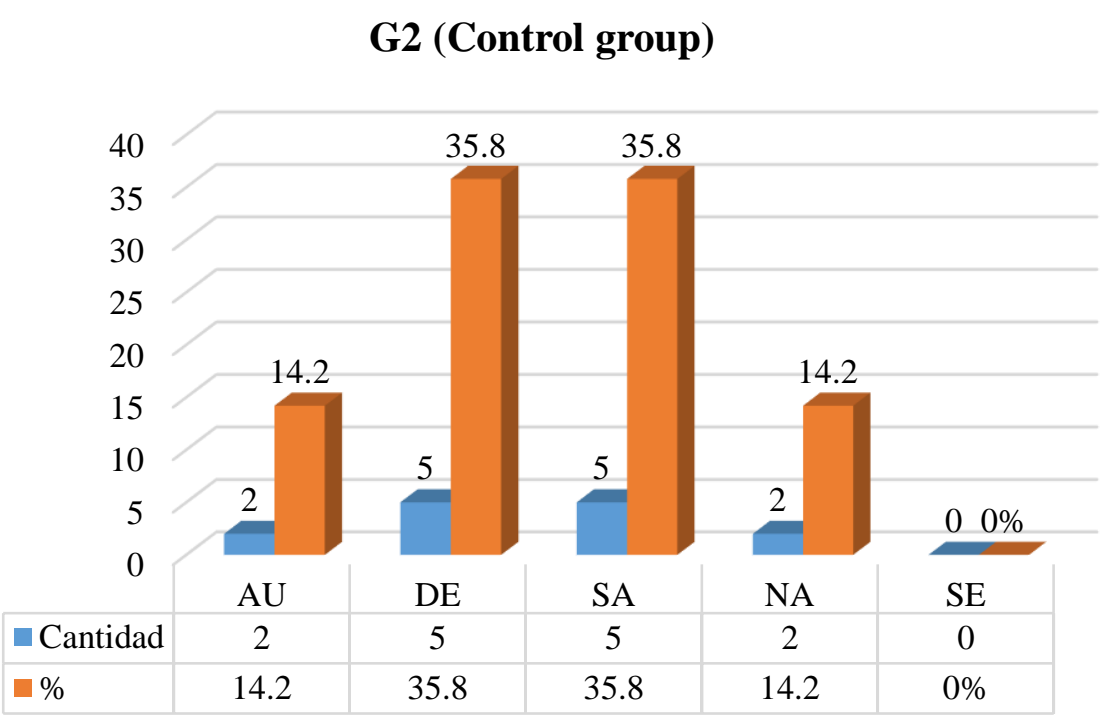

Source: Own elaboration

From the results obtained, it can be seen that the experimental group to which the flipped classroom model was applied obtained $28.6 \%$ more students who obtained Autonomous (AU) which makes it a very significant result with advantages for this model by having a more comprehensive approach. As for the students who obtained Outstanding (SD), the control group was superior with $14.4 \%$, while the percentage of students with Satisfactory (SA) was exactly the same in both groups.

However, it should be noted that in the experimental group there were no Non-Accredited students (NA) while in the control group there were, similarly in no group registered students Without Assessment (SE).

\subsection{Conclusions}

The present work examined the results obtained with the implementation of the flipped classroom model in a Technological University in the career of Higher University Technician in Information and Communication Technologies: Multiplatform Development Area and in the Multiplatform Mobile Development course, after implemented for a quarter. 
Based on the results, the analysis components obtained conform very well to the revised state of the art on the applied model. The advantages and disadvantages detected coincide with the flipped classroom construct, in addition to contributing to the transversal skills of the use of ICT, especially considering the moment we live today due to the pandemic in education with distance classes. On the other hand, this model allows the teacher to accompany the students to promote their autonomous work, coinciding with the results of Erol (2020).

Additionally, the experience and results obtained with the experimental group where the flipped classroom was applied were satisfactory since the strategy was functional and the students obtained good academic results in both, the formative and summative evaluations, so that It is considered to be highly recommended at the higher level and particularly in the Technological Universities subsystem.

Regarding the quantitative learning results, they were very acceptable given that in the experimental group there were no failed students, while in the control group 2 students did not accredit the subject, also obtaining a greater number of students with an Autonomous result in the experimental group.

However, it should be noted that it is very important for this model that the teacher designs activities that are meaningful with clear instructions for the students, as well as effective intervention during synchronous classes, where learning is socialized, knowledge is evaluated prior, the student is motivated, collaborative work is promoted and feedback is given in a timely manner. Additionally, it is recommended to implement techno-pedagogical mediation strategies to assist in the teaching-learning process (Ramírez-Hernández, Cortés \& Díaz, 2020).

Regarding the hypothesis raised at the beginning of the research project, it is accepted since according to the quantitative data obtained, it was indeed possible to corroborate that with the implementation of the flipped classroom, the autonomous learning of the students of the Technological Universities can be improved.

However, despite the tests carried out, there is still a way to go, it is considered important as future work to apply an instrument to measure the degree of satisfaction of the participants, both students and teachers, that serves as feedback for the continuous improvement of the framework of work, as well as applying it in more subjects to make a comparison in greater detail.

\subsection{References}

Adriazola Uribe, A., Duran Jimenez, G., \& Flores Troncoso, M. (2020). Flipped Classroom: una experiencia para fortalecer el aprendizaje en Medicina Veterinaria. Educ. Pesqui, 1-16. Retrieved from: http://www.scielo.br/pdf/ep/v46/1517-9702-ep-46-e214200.pdf

Aguilera-Ruiz, C., Manzano-León, A., Martínez-Moreno, I., Lozano-Segura, M., \& Casiano Yanicelli, C. (2017). El modelo Flipped Classroom. INFAD Revista de Psicología, 261-266. Retrieved from: https://www.redalyc.org/pdf/3498/349853537027.pdf

Artero Escartín, I., \& Domeque Claver, N. (2018). Dar 'la vuelta' a la enseñanza. Una experiencia de Flipped Classroom en Economía Pública. Revista electrónica sobre la enseñanza de la Economía Pública, 51-75. Retrieved from: http://e-publica.unizar.es/wp-content/uploads/2018/02/3\%C2\%BA17209-maquetado.pdf

Balçıkanl1, C. (2010). Learner Autonomy In Language Learning: Student Teachers' Beliefs. Australian Journal of Teacher Education, 89-103. Retrieved from: https://ro.ecu.edu.au/cgi/viewcontent.cgi?article=1331\&context=ajte

Berenguer Albaladejo, C. (2016). Acerca de la utilidad del aula invertida o flipped classroom. XIV Jornadas de Redes de Investigación en Docencia Universitaria: investigación, innovación y enseñanza universitaria, (págs. 1466-1480).

Bergmann, J., \& Sams, A. (2012). Flip Your Classroom: Reach Every Student in Every Class Every Day. Washington: International Society for Technology in Education. 
Burbat, R. (2016). El aprendizaje autónomo y las TIC en la enseñanza de una lengua extranjera: ¿Progreso o retroceso? Porta Linguarum, 37-51. Retrieved from: https://www.ugr.es/ portalin/articulos/PL_numero26/ART3_Ruth\%20Burbat.pdf

Coordinación General de Universidades Tecnológicas. (2008). Fortalecimiento del Subsistema de Universidades Tecnológicas "Su evolución al nivel de estudioa 5A". México: Secretaría de Educación Pública.

Del Arco Bravo, I., Flores Alarcia, Ó., \& Silva García, P. (2019). El desarrollo del modelo flipped classroom en la la universidad: impacto de su implementación desde la voz del estudiantado. Revista de Investigación Educativa, 451-459. Retrieved from: https://revistas.um.es/rie/article/view/327831/266561

Díaz Pérez, A., Cegarra Conde, J., \& Serra López, L. (2021). Aprendizaje invertido: Un modelo emergente para el aprendizaje de la programación en estudiantes universitarios. Mérito Revosta de Educación, 52-63. Retrieved from: https://revistamerito.org/index.php/merito/article/view/282/837

Erol Sahin, A. N. (2020). Using the Flipped Classroom Model in the History Course: A Learning Experience. International Journal of Educational Methodology, 113-121. Retrieved from: https://ijem.com/using-the-flipped-classroom-model-in-the-history-course-a-learning-experience

Espinoza Romero, D. A., \& Velázquez Vázquez, D. (2017). Aprendizaje Autónomo en Alumnos de Educación Superior. Avances en Liderazgo y Mejora de la (págs. 219-222). Madrid: Red de Investigación sobre Liderazgo y Mejora de la Educación - RILME. Retrieved from: https://repositorio.unican.es/xmlui/bitstream/handle/10902/13480/ModeloLessonStudy.pdf?sequence=1 \&isAllowed $=\mathrm{y}$

Flores, O., Del Arco, I., \& Silva , P. (2016). The flipped classroom model at the university: analysis based on professors' and students' assessment in the educational field. International Journal of Educational Technology in Higher Education, 1-12. Retrieved from: https://educationaltechnologyjournal.springeropen.com/articles/10.1186/s41239-016-0022-1

García-Gil, D., \& Cremades-Andreu, R. (2019). Flipped classroom en educación superior. Revista Mexicana de Investigación Educativa, 102-123. Retrieved from: http://www.scielo.org.mx/pdf/rmie/v24n80/1405-6666-rmie-24-80-101.pdf

Gilboy, M., Heinerichs, S., \& Pazzaglia, G. (2015). Enhancing Student Engagement Using the Flipped Classroom. Journal of Nutrition Education and Behavior, 109-114. Retrieved from: https://www.sciencedirect.com/science/article/abs/pii/S1499404614006381

Hernández-Sampieri, R., Fernández Collado, C., \& Baptista Lucio, P. (2003). Metodología de la investigación. México: Mc Graw Hill.

Kardas, F., \& Yesilyaprak, B. (2015). A Current Approach To Education: Flipped learning model. Journal of Faculty of Educational Sciences, 103-121. Retrieved from: https://dergipark.org.tr/tr/download/article-file/508607

Paladines-Ugalde, R. E. (2016). Incidencia de la autonomía educativa y el aprendizaje de los estudiantes del colegio Juan Montalvo del cantón Manta. Dominio de las Ciencias, 133-148. Retrieved from: https://dialnet.unirioja.es/servlet/articulo?codigo $=5761633$

Pienta, N. (2016). A "Flipped Classroom" Reality Check. Journal of Chemical Education, 1-2. Retrieved from: https://pubs.acs.org/doi/abs/10.1021/acs.jchemed.5b00996

Ramírez Hernández, M., Cortés Palma, E., \& Díaz Alva, A. (2020). Estrategias de mediación tecnopedagógicas en los ambientes virtuales de aprendizaje. Apertura, 132-149. Retrieved from: http://www.udgvirtual.udg.mx/apertura/index.php/apertura/article/view/1875 
Reyes Roa, M. L. (2017). Desarrollo de la competencia de aprendizaje autónomo en estudiantes de Pedagogía en un modelo educativo basado en competencias. Revista de Estudios y Experiencias en Educación, 67-82. Retrieved from: https://www.redalyc.org/pdf/2431/243153684004.pdf

Sánchez Godoy, I., \& Casal Madinabeitia, S. (2016). El desarrollo de la autonomía mediante las técnicas de aprendizaje cooperativo en el aula de 12. Porta Linguarum 25, 179-1790. Retrieved from: https://dialnet.unirioja.es/servlet/articulo?codigo $=5414080$

Sánchez Rodríguez, J., Ruiz Palmero, J., \& Sánchez Vega, E. (2017). Flipped classroom. Claves para su puesta en práctica. Revista de Educación Mediática y TIC, 336-358. Retrieved from: https://www.uco.es/ucopress/ojs/index.php/edmetic/article/view/5832

Sánchez-Cruzado , C., \& Sánchez-Compaña, M. T. (2020). El modelo flipped classroom, una forma de promover la autorregulación y la metacognición en el desarrollo de la educación estadística. Revista Interuniversitaria de Formación del Profesorado, 121-142. Retrieved from: https://recyt.fecyt.es/index.php/RIFOP/article/view/77713

Santiago, R. (2016). Dodecaedro Flipped. 10 de las caras que component Flipped Classroom. Revista Flipped Classroom., 1-14.

Sarramona, J. (2011). Autonomía y calidad de la educacón. XII Congreso internacional de teoría de la educación (págs. 1-15). Barcelona: Universidad Autónoma de Barcelona. Retrieved from: http://www.cite2011.com/Ponencias/JSarramona.pdf

Solórzano-Mendoza, Y. (2017). Aprendizaje autónomo y competencias. Dominio de las Ciencias, 241253. Retrieved from: https://dominiodelasciencias.com/ojs/index.php/es/article/view/390

Zainuddin, Z., \& Halili, S. (2016). Flipped Classroom Research and Trends from Different Fields of Study. International Review of Research in Open and Distributed Learning, 3013-340. Retrieved from:https://files.eric.ed.gov/fulltext/EJ1102721.pdf 